\title{
Deep Neck Infection Caused by Eikenella Corrodens Coinfection with Streptococcus Mitis and Streptococcus Oralis in an Infant
}

\author{
Eikenella Corrodens, Streptococcus Mitis ve Streptococcus Oralis \\ Kaynaklı Derin Boyun Enfeksiyonu
}

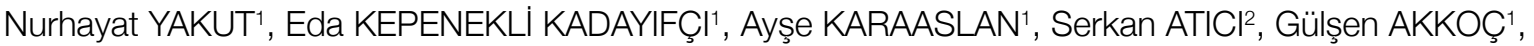 \\ Sevliya ÖCAL DEMIR ${ }^{1}$, Adem BINNETOĞLU ${ }^{3}$, Ahmet SOYSAL ${ }^{4}$, Mustafa BAKIR ${ }^{5}$
}

\author{
'Marmara University, Faculty of Medicine, Department of Children's Health and Diseases, Pediatric Infectious Diseases Department, \\ İstanbul, Turkey \\ ${ }^{2}$ Child Health and Disease Specialist, İstanbul, Turkey \\ ${ }^{3}$ Marmara University, Faculty of Medicine, Department of Ear, Nose and Throat, İstanbul, Turkey \\ ${ }^{4}$ Pediatric Infectious Diseases Specialist, İstanbul, Turkey \\ ${ }^{5}$ Child Allergy-Immunology Specialist, İstanbul, Turkey
}

\begin{abstract}
Eikenella corrodens is a gram-negative, facultative rod that can rarely cause infections in children.

Herein we describe a sixteen-month-old boy who had been admitted with symptoms of fever and limited neck mobility. Computed tomography has scanned $10 \times 10 \mathrm{~mm}$ abscess formation at the prevertebral space. Culture of the abscess drainage material yielded Eikenella corrodens, Streptococcus mitis and Streptococcus oralis. He was successfully treated with vancomycin and cefepime for 14 days without any sequelae.

Eikenella corrodens is a critical microorganism that causes infections, usually with other organisms. Optimal therapy is a combination of surgical intervention and antibiotic therapy in deep neck infections.
\end{abstract}

Key Words: Deep neck infection, Eikenella corrodens, Streptococcus mitis, Streptococcus oralis

\section{ÖZET}

Eikenella corrodens oral ve gastrointestinal florada bulunan gram negatif, fakültatif bir basildir. Çocuklarda nadir görülen bir enfeksiyon etkenidir.

Burada acil servise ateş ve boyun hareketlerinde kısıtlllık şikayetleriyle başvuran onaltı aylik erkek hasta sunulmuştur. Bilgisayarlı tomografide prevertebral alanda $10 \times 10 \mathrm{~mm}$ abse formasyonu tespit edilen hastanın abse drenajndan gönderilen kültüründe vankomisin ve sefepim duyarlı E. corrodens, sadece vankomisin duyarlı Streptococcus mitis ve Streptococcus oralis üredi. Tedavi vankomisin ve sefepim olarak düzenlenerek 14 güne tamamlandı.

E. corrodens diğer mikroorganizmalarla birlikte enfeksiyonlara yol açan önemli bir patojendir. Derin boyun enfeksiyonlarında optimal tedavi, cerrahi girişim ve antibiyoterapi ile sağlanabilir.

Anahtar Sözcükler: Derin boyun enfeksiyonu, Eikenella corrodens, Streptococcus mitis, Streptococcus oralis

\section{INTRODUCTION}

Eikenella corrodens (formerly known as Bacteroides corrodens) is a gram-negative and facultative rod in oral, gastrointestinal and genitourinary flora, that was first characterized by Eiken in 1958 (1). E. corrodens grow slowly and the small and grayish colonies may therefore be overlooked during bacteriological examination (2). It may become pathogenic in case of breakdown of mucocutaneous barriers because the organism gains access to deeper tissues. Infections with E. corrodens infections are usually polymicrobial and may most frequently include a-hemolytic streptococci (3). Eikenella species can cause various infective diseases such as head and neck infection pulmonary infection, empyema, arthritis, endocarditis, human and animal bite wound infection, skeletal infection and cutaneous infection (4). In most reported cases, it causes indolent and benign infections (5). However, invasive infections caused by 
this organism are reported. Although pediatric infections due to E. corrodens are much less common, there is a particularly high risk for serious infections (6). We report a case of deep neck infection caused by Eikenella corrodens coinfection with Streptococcus mitis and Streptococus oralis in an infant successfully treated with surgical drainage and antibiotic treatment.

\section{CASE REPORT}

A previously healthy sixteen-month-old boy presented to the emergency room with symptoms of fever and limited neck mobility for the last five days, which was unresponsive to 5 days of intramuscular ampicillin-sulbactam treatment. On admission, his physical examination revealed fever $\left(>38^{\circ} \mathrm{C}\right)$, restlessness, exudative tonsillitis and limited neck mobility. The other system findings (respiratory, gastrointestinal, genitourinary) were normal. His vital signs were normal except for body temperature $\left(>38^{\circ} \mathrm{C}\right)$. Laboratory tests showed white blood cell count of $15700 / \mathrm{ml}$, C-reactive protein of $74.7 \mathrm{mg} / \mathrm{L}$, erythrocyte sedimentation rate of $80 \mathrm{~mm} / \mathrm{h}$ and normal biochemistry values. Serum levels of Immunoglobulin A,G,M, measurement of oxidative burst in neutrophils and flow cytometry were normal. We consulted the patient to an otolaryngologist and computed tomography was performed because of suspicion of deep neck infection. Computed tomography (CT) scan showed $10 \times 10 \mathrm{~mm}$ abscess formation at the prevertebral space (Figure1). The patient was evaluated by an Otolaryngology specialist and underwent surgery for drainage of the abscess, The patient was secured to the operating table in the Trendelenburg position with the aim of preventing abscess content from escaping to the airways. The patient's neck was extended. A Boyle Davis retractor was placed to obtain visualization of the oropharyngeal wall. $14 \mathrm{Fr}$ suction catheter was inserted through the nasal passage to retropalatal space then proximal and distal ends of the catheter was fixed wit a clamp to visualize the mucosa overlying the retropharyngeal space. The mucosa overlying the fluctuating mass was incised with No 15 blade. When the abscess content was reached, the incision was enlarged to provide drainage of the all abscess content. After drainage of the abscess content, the cavity was irrigated with $1000 \mathrm{cc}$ isotonic sodium chloride. Microbiological samples were obtained and empirical intravenous ampicillin-sulbactam therapy was started. Because of severe infection in a toddler, we did not administer oral therapy. Abscess formation was not observed after drainage (Figure 2). Twelve hours later than the drainage, the Bact Alert device gave a signal indicating growth of microorganism. On gram-stain, gram-negative bacilli were seen. One day later, Vitek MS identified the microorganism as Eikenella corrodens, S. mitis and S. oralis, and reliability was 99.9\%. The E test used to describe antimicrobiological susceptibility showed that E. corrodens was only susceptible to vancomycin and cefepime while $S$. mitis and $S$. oralis were only susceptible to vancomycin. The therapy was changed to vancomycin and cefepime. Antibiotherapy was continued for 14 days and the patient was discharged without any sequelae.

\section{DISCUSSION}

Eikenella corrodens has been increasingly isolated in both immunosuppressed patients, and more recently in immunocompetent patients. Although intravenous drug users and elderly

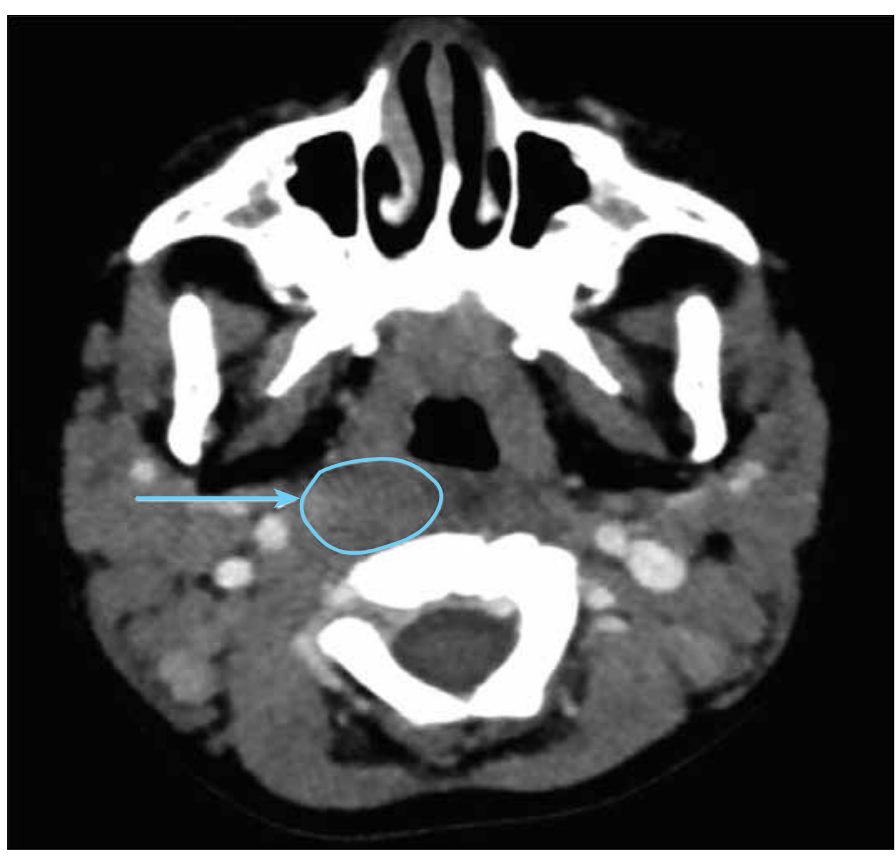

Figure 1: Preoperative contrast-enhanced CT of the neck showing an asymmetric enlargement at the right prevertebral space.

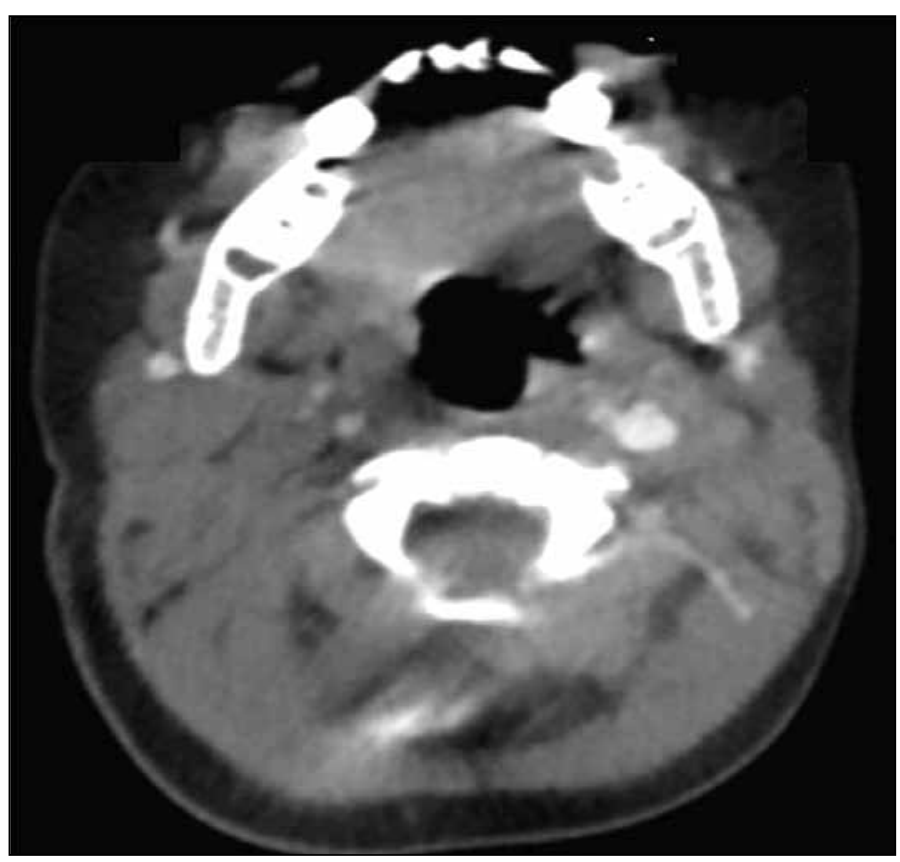

Figure 2: Postoperative contrast-enhanced CT Asymmetric enlargement was not observed. 
patients are the high-risk groups for E. corrodens infections, children are at particularly high risk for critical infections with $E$. corrodens (6). Eikenella species can cause various infective diseases ranging from head and neck infection pulmonary infection, empyema, arthritis, endocarditis to human and animal bite wound infection, skeletal infection and cutaneous infection (4). A review of $E$. corrodens infection in children and adolescents in 54 cases revealed that $40.7 \%$ of pediatric infections were located in the head and neck region (7). It was the expected outcome because Eikenella species was in the normal flora of oral cavity (8). Infection can spread hematogenously and be serious when mucosal or skin barriers are destroyed. A study of 43 cases of invasive $E$. corrodens infections revealed that $56 \%$ of infections appeared in the head and neck (9). The other study of 22 cases of head and neck infections due to $E$. corrodens revealed that 11 patient were under 15 years old (10). Report of an acute suppurative thyroiditis caused by $E$. corrodens in children has also been in children (11). E. corrodens coinfection is common and a-hemolytic streptococci are the most common co-isolated bacteria as indicated by our present case. Because of slow growth and small, grayish, flat colonies, it may be overlooked during definitive diagnosis tests. Eikenella species can be overgrown by the other organisms in case of polymicrobial infections, so may be missed. E. corrodens has been shown to have different antibiotic susceptibility pattern (12). Most isolates are susceptible to many antibiotics such as penicilin, ampicillin, amoxicillin-clavulanic acid, trimethoprimsulfamethoxazole, second and third-generation cephalosporins and fluoroquinolones (13). However, these organisms are usually resistant to clindamycin, erythromycin and metronidazole. E. corrodens was only susceptible to vancomycin and cefepime in our patient. Drainage of abscess is essential to recovery from some infections as performed on our patient.

\section{CONCLUSION}

E. corrodens is a critical microorganism in children. It can be a pathogen in any wound contaminated with human oral secretions, particularly in head and neck infections. $E$. corrodens should be considered a pathogenic microorganism when isolated from a sterile site. Due to the surgical drainage performed under sterile conditions and the existence of symptoms, we considered the microorganism as responsible agent for infection. Depending on the location and severity of infection, the combination of surgical approach and antibiotics should be emphasized.

\section{REFERENCES}

1. Eiken M. Studies on an anaerobic, rod-shaped, gram-negative microorganism: Bacteroides corrodens sp. Acta Pathol Microbiol Scand 1958; 43:404-16.

2. Dorff GJ, Jackson LJ, Rytel MW. Infectious with Eikenella corrodens: A newly recognized human pathogen. Ann Intern Med 1974;80:305-9.

3. Suwanagool S, Rothkopf MM, Smith SM, LeBlanc D, Eng R. Pathogenicity of Eikenella corrodens in humans. Arch Intern Med 1983;143:2265-8.

4. Arana E, Vallcanera A, Santamaría JA, Sanguesa C, Cortina H. Eikenella corrodens skull infection: A case report with review of the literature. Surg Neurol 1997;47:389-91.

5. Stoloff AL, Gillies ML. Infections with Eikenella corrodens in a general hospital: A report of 33 cases. Reviews of Infectious Diseases 1986;8:50-3.

6. Raffensperger JG. Eikenella corrodens infections in children. J Pediatr Surg 1986;21:644-6.

7. Paul K, Patel SS. Eikenella corrodens infections in children and adolescents: Case reports and review of the literature. Clin Infect Dis 2001;33:54-61.

8. Tveteras K, Kristensen S, Bach V, Ravio O. Eikenella corrodens: A recently recognized pathogen in head and neck infections. Journal of Laryngology and Otology 1987;101:592-4.

9. Sheng WS, Hsueh PR, Hung CC, Teng LJ, Chen YC, Luh KT. Clinical features of patients with invasive eikenella corrodens infections and microbiological characteristics of the causative isolates. Eur $\mathrm{J}$ Clin Microbiol Infect Dis 2001;20:231-6.

10. Udaka T, Hiraki N, Shiomori T, Miyamoto H, Fujimura T, Inaba T, et al. Eikenella corrodens in head and neck infections. Journal of Infection 2007;54:343-8.

11. Yoshino $Y$, Inamo $Y$, Fuchigami T, Hashimoto $K$, Ishikawa T, Abe $O$ et al. A pediatric patient with acute suppurative thyroiditis caused by Eikenella corrodens. J Infect Chemother 2010;16:353-5.

12. Brooks GF, O'Donogue JM, Rissing JP, Soapes K, Smith JW. Eikenella corrodens, a recently recognized pathogen: Infections in medical-surgical patients and in association with methylphenidate abuse. Medicine 1974;53:325-42.

13. Tami TA, Parker GS. Eikenella corrodens: An emerging pathogen in head and neck infections. Arch Otolaryngol 1984;110:752-4. 